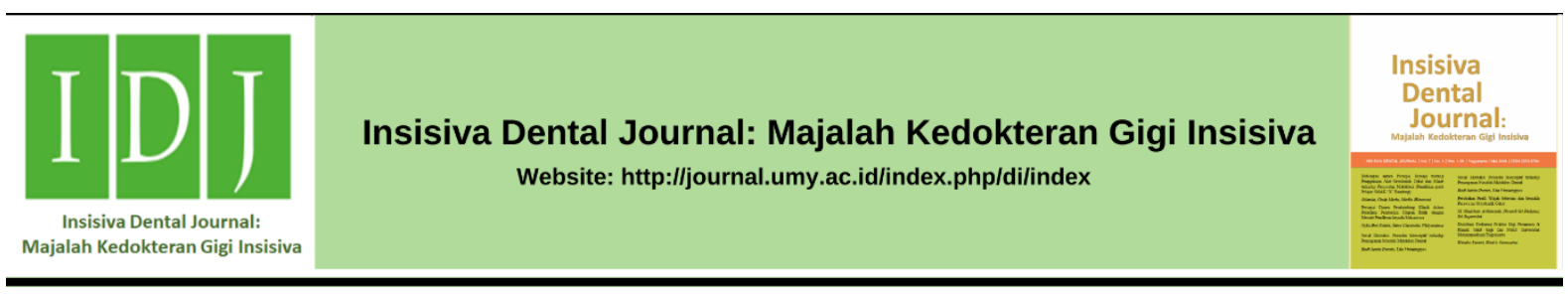

Research Article

\title{
Gargling Effect of Zamzam Water on Salivary pH
}

\author{
Fadlun Alawiyah', Shanty Chairani',*, Danica Anastasia ${ }^{3}$ \\ ${ }^{1,2,3}$ Program Studi Kedokteran Gigi, Fakultas Kedokteran, Universitas Sriwijaya, Negara Bukit Besar, Jalan Srijaya Negara, Bukit Lama, Ilir \\ Barat I, Palembang, Sumatera Selatan, Indonesia
}

Received date: November $6^{\text {th }}, 2020$; reviewed date: April $7^{\text {th }}, 2021$; revised date: May $6^{\text {th }}, 2021$; accepted date: May $27^{\text {th }}, 2021$ DOI : 10.18196/di.v10i1.10178

\begin{abstract}
Caries is a multifactorial infection disease that happened during the decrease of salivary pH caused by acids from bacterial metabolism. Bicarbonate is an important buffer component in saliva that can help neutralize salivary pH. Zamzam water has high bicarbonate content. This study aimed to evaluate the effect of gargled with Zamzam water on salivary $\mathrm{pH}$. This experimental research was done with pre-test and post-test control group design involving 40 dentistry students at the University of Sriwijaya aged 18-23 years old, with DMF-T score $\leq 3$. Samples were divided into 2 groups, the Zamzam water group, and thedistilled water group. Samples gargled their mouth with $10 \mathrm{ml}$ of a $25 \%$ sucrose solution for one minute, then saliva was collected with spitting method and salivary $\mathrm{pH}$ was measured with digital pH meter and recorded as initial pH. Samples then gargledwith $20 \mathrm{ml}$ of Zamzam water or distilled water according to each group for one minute, then saliva was collected in the same way as before, and $\mathrm{pH}$ was measured and recorded as final $\mathrm{pH}$. Data were analyzed with paired $t$-test and Mann-Whitney. The result showed that salivary $\mathrm{pH}$ increased significantly after gargled with Zamzam water $(p>0,05)$. The mean difference of salivary $p H$ aftergargled with Zamzam water was statistically higher than distilled water $(p>0,05)$. In conclusion, Gargled with Zamzam water can increase salivary $\mathrm{pH}$.
\end{abstract}

Keywords: Bicarbonate; Gargled; Salivary pH; Zamzam Water

\section{INTRODUCTION}

Caries remains the main problem in most society in the world. Decay Missing Filling Tooth (DMFT) index in Indonesia based on the result of basic health research (Riset Kesehatan Dasar/Riskesdas) 2018 was $7,1.1$

This result showed that Indonesia belongs to the high caries category following the WHO classification. Caries is multifactorial infection disease caused by acids produced from bacterial metabolism on the tooth. ${ }^{2}$ Bacteria, host (tooth surface and saliva), diet (especially sucrose intake) and time are the main factors that influence the development of dental caries. ${ }^{3}$ Individual systemic health, social-economic status, and the implementation of oral health care are also related to dental caries. Acids produced from bacteria will reduce the salivary $\mathrm{pH}$, continuous decrease of salivary $\mathrm{pH}$ to below critical $\mathrm{pH}$ will be caused demineralization. $\frac{3}{}$ The acid can be neutralized by the saliva buffer system. Neutral $\mathrm{pH}$ allows the mineral to be deposited back into enamel crystals, called remineralization process..$^{4}$

Saliva plays an important role in oral clearance. The salivary flow rate provides washing action that flushes away nonadherent bacteria and debris. Saliva maintains tooth integrity by modulating remineralization because it contains

\footnotetext{
* Corresponding author, e-mail: shanty.c@fk.unsri.ac.id
} 
calcium and phosphate. $\frac{5}{}$ Normal salivary $\mathrm{pH}$ is from 6,2 to $7,6 \cdot{ }^{6}$ Saliva could help neutralize the acid from foods and drinks by salivary buffer system. Bicarbonate is the main buffer component in saliva. $\frac{3}{3}$ Bardow et al reported that a high $\mathrm{pH}$ is directly proportional to a high bicarbonate concentration. $\underline{5}$

Dental hard tissues will be demineralized in acid condition especially in critical salivary $\mathrm{pH} 5,5$ or lower. ${ }^{2}$ Gargling with water promptly after eating is suggested to remove the acid from mouth. Then followed with brushing teeth after 3060 minutes later. It also helps remove debris that is attached to teeth. - There are so many kinds of water that can be used for gargling, one of them is Zamzam water.

Zamzam water is holy natural water. It is termed a great gift from God. Zamzam water has healing properties. It is rich in a variety of minerals and has high $\mathrm{pH}$ value (average $\mathrm{pH}$ of 8$){ }^{\underline{7}}$ Mineral compositions in Zamzam water are calcium, magnesium, potassium, fluoride, bicarbonate, and chloride. ${ }^{-}$It is reported that Zamzam water has the ability to inhibit the growth and proliferation of cancer cell. ${ }^{\stackrel{9}{ }}$ Zamzam water also have an antioxidant effect. ${ }^{10,11}$ Fauzi et al. reported that Zamzam water can help prevent osteoporosis because its calcium content. $\frac{12}{}$ Zamzam water also can increase the microhardness of the enamel surfaces. $\underline{13}$

Zamzam water has high bicarbonate concentration which the main buffer component. The aim of this study was to evaluate the effect of gargled with Zamzam water on salivary $\mathrm{pH}$.

\section{MATERIALS AND METHOD}

This experimental study was with pretest and posttest control group design. All procedures in this study had been approved by The Health Research Review Committee of Mohammad Hoesin Central Hospital and Faculty of Medicine, University of Sriwijaya, Indonesia (No. 067/kepkrsmhfkunsri/2019).

This study involved 40 dentistry students at the University of Sriwijaya, age between 18-23 years old, and DMFT score $\leq 3$. Subjects with a history of systemic disease, salivary gland disease, smoking, using any systemic medication, and under orthodontic treatment were excluded from the study. Subjects were divided into two groups, Zamzam water group, and the distilled water group. Zamzam water that used in this study is distributed by National Water Company (NWC), Saudi Arabia. Bicarbonate and $\mathrm{pH}$ value of this Zamzam water had been examined with results of $309,52 \mathrm{mg} / \mathrm{L}$ of bicarbonate concentration and $\mathrm{pH}$ 7,9 (Figure 1).

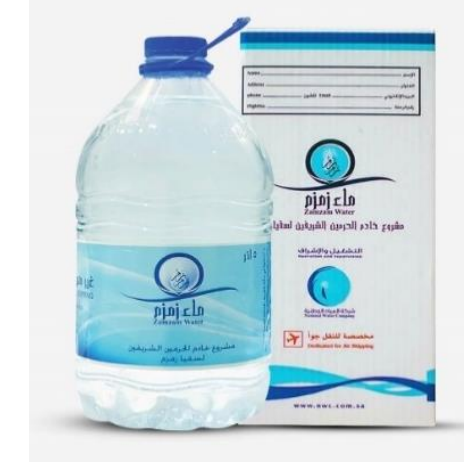

Figure 1. Zamzam Water

The saliva samples were collected between 9-12 a.m. ${ }^{14}$ All subjects were given clear instructions to refrain from eating one hour before saliva collection. Subjects were asked to brush their teeth without dentifrice to remove debris from the tooth surface before the study was conducted. All subjects gargled their mouth with $20 \mathrm{ml}$ of $25 \%$ sugar solution for the purpose to reduce salivary $\mathrm{pH} . \underline{15}$ Subjects gargled by swishing the entire content in the mouth and expectorate after 1 minute. Five minutes later saliva sample was obtained, then $\mathrm{pH}$ was measured by electrical $\mathrm{pH}$ meter (Hanna Instruments, Romania) and recorded as initial $\mathrm{pH}$. $\mathrm{pH}$ meter was calibrated before the study was conducted with buffering solutions. Immediately after initial saliva collection,subjects gargled the mouth with $20 \mathrm{ml}$ of Zamzam water or distilled water for 1 minute in the same way as before according to each group. Five minutes later saliva was collected, then $\mathrm{pH}$ was measured and recorded as final $\mathrm{pH}$.

The data were analyzed with a dependent $\mathrm{t}$-test to compare the salivary $\mathrm{pH}$ 
before and after gargled with Zamzam water and distilled water. Mean difference of salivary $\mathrm{pH}$ among groups was analyzed with the Mann-Whitney $U$ test. The significance level was set as $\mathrm{p}<0,05$.

\section{RESULT}

All salivary $\mathrm{pH}$ data were done with normality test to see the distribution of data. Results of the Shapiro-Wilk normality test showed that salivary $\mathrm{pH}$ data before and after gargled with Zamzam water and distilled water were normal $(p>0,05)$. It fulfills the parametric test requirement with paired t-test to compare salivary $\mathrm{pH}$ before and after gargled with Zamzam water and distilled water. Table 1 represents the $\mathrm{pH}$ values of both groups before and after gargling.

Table 1. Effect of gargled with Zamzam water and distilled water to salivary $\mathrm{pH}$

\begin{tabular}{llll}
\hline \multirow{3}{*}{ Groups } & $\begin{array}{l}\text { Mean } \\
\text { deviation of salivary } \mathrm{pH}\end{array}$ & \multicolumn{1}{c}{ ptandard } \\
\cline { 2 - 3 } & $\begin{array}{l}\text { Before } \\
\text { gargled }\end{array}$ & $\begin{array}{l}\text { After } \\
\text { gargled }\end{array}$ & \\
\hline $\begin{array}{l}\text { Zamzam } \\
\text { water }(\mathrm{n}=20)\end{array}$ & $6,60 \pm 0,23$ & $6,77 \pm 0,24$ & $0,00^{*}$ \\
$\begin{array}{l}\text { Distilled } \\
\text { water }(\mathrm{n}=20)\end{array}$ & $6,53 \pm 0,26$ & $6,57 \pm 0,27$ & 0,15 \\
\hline
\end{tabular}

The mean $\mathrm{pH}$ before gargling with Zamzam water was $6,60 \pm 0,23$ and increased to $6,77 \pm 0,24$ after gargling which was statistically significant at $p=0,00$. The mean $\mathrm{pH}$ before gargling with distilled water was $6,53 \pm 0,26$ and increased to $6,57 \pm 0,27$ after rinsing which was statistically nonsignificant at $\mathrm{p}=0,15$.

The mean difference of salivary $\mathrm{pH}$ in the Zamzam water group was 0,18 and the distilled water group was 0,04. Results of the Shapiro-Wilk normality test showed that the mean difference of salivary $\mathrm{pH}$ in both groups was 0,00 and 0,01 . It mean the data were not normal $(\mathrm{p}<0,05)$, data then were transformed but the result still not normal. The data then were analyzed with an alternative non-parametric Mann Whitney test to compare the mean difference of salivary $\mathrm{pH}$ among groups.
Table 2 represents the results ofthe MannWhitney test.

Table 2. Comparisons of median difference of salivary $\mathrm{pH}$ between Zamzam water and distilled water group

\begin{tabular}{llll}
\hline Groups & $\begin{array}{l}\text { Median } \\
\text { (Minimum- } \\
\text { Maximum) }\end{array}$ & $\begin{array}{l}\text { Mann- } \\
\text { Whitney }\end{array}$ & $\begin{array}{l}\text { Asymp } \\
\text { Sig (2- } \\
\text { tailed) }\end{array}$ \\
\hline $\begin{array}{l}\text { Zamzam } \\
\text { water } \\
(\mathrm{n}=20)\end{array}$ & $0,2(0,0-0,3)$ & & \\
$\begin{array}{l}\text { Distilled } \\
\text { water } \\
(\mathrm{n}=20)\end{array}$ & $0,1(-0,3-0,2)$ & & \\
\hline
\end{tabular}

The median value of the Zamzam water group was higher than the distilled water group. According to Mann-Whitney test (table 2), there was a significant difference between Zamzam water group and distilled water group.

\section{DISCUSSION}

Results showed that gargling with Zamzam water increased salivary $\mathrm{pH}$. Increased salivary $\mathrm{pH}$ after gargled with Zamzam water can be associated with high bicarbonate content in Zamzam water. Various studies stated that Zamzam water contains high bicarbonate which is around $172 \mathrm{mg} / \mathrm{L}-285 \mathrm{mg} / \mathrm{L} .{ }^{8}, 16$ Zamzam water in this study has been tested for bicarbonate content and the result is $309.52 \mathrm{mg} / \mathrm{L}$. Bicarbonate will bind $\mathrm{H}^{+}$ions from acids and will produce carbonic acid which is immediately converted to water and carbon dioxide so that salivary $\mathrm{pH}$ will increase. $\underline{3}$

The results of this study showed that after gargled with $20 \mathrm{ml}$ of Zamzam water which every $20 \mathrm{ml}$ containing $0,3 \%$ bicarbonate could increase salivary $\mathrm{pH}$ from 6,60 to 6,77 . That $\mathrm{pH}$ score is in the normal $\mathrm{pH}$ range of saliva. The results of this study were in accordance with the study of Abbate et al. which stated that the use of sodium bicarbonate-based spray can increase salivary $\mathrm{pH}$ from 6,5 to $6,9.17$

Salivary $\mathrm{pH}$ should be maintained in a normal range. When salivary $\mathrm{pH}$ is higher than 7, it will generate saturated conditions, which will make calcium and phosphate precipitate, then form calculus. ${ }^{3,4}$ The study 
from Wulandari et al showed that there was a strong correlation between $\mathrm{pH}$ and buffer capacity of saliva with the accumulation of calculus. $\underline{18}$

These results showed that after gargled with distilled watercould increase salivary $\mathrm{pH}$ from 6,53 to 6,57 . In general, salivary $\mathrm{pH}$ will increase due to the salivary buffer system. According to the Stephan curve, the salivary $\mathrm{pH}$ will drop in the initial 15 minutes after exposure to sucrose and will return to the initial $\mathrm{pH}$ after 20 to 60 minutes. $\stackrel{2}{\text { Gargling with a distilled water }}$ can help clear the attachment of the substrate in the oral cavity so that it can support the salivary buffer system to neutralizing the oral cavity. Gargling with water after eating is very important to maintain oral clearance. Osso et al. said that gargling with tap water was as effective as brushing or gargling with mouthwash to increase salivary $\mathrm{pH}$ and beneficial in reducing the possibility of caries formation. $\underline{19}$

The weakness of this study was that the initial $\mathrm{pH}$ obtained after rinsing with sucrose still in the normal range of salivary $\mathrm{pH}$. An alternative solution that can be used to make salivary $\mathrm{pH}$ lower is orange juice, as reported by Dehgan et al.which stated that after rinsing $20 \mathrm{ml}$ of orange juice salivary $\mathrm{pH}$ decreasedto 4.98-5.20. ${ }^{20}$ It aims to see the ability of Zamzam water to increase salivary $\mathrm{pH}$ in acidic conditions.

This study suggested that gargling with Zamzam water can increase salivary $\mathrm{pH}$. In the future Zamzam water is expected as an agent to prevent the formation of caries. Besides rich bicarbonate, Zamzam water also contains high calcium $(114 \mathrm{mg} /$ L) and phosphate $(0,15 \mathrm{mg} / \mathrm{L})$, which can help in the remineralization process. Zamzam water also reported contain fluoride $(0,59 \mathrm{mg} / \mathrm{L})$. Fluoride has antibacterial activity as reported by Perala et al. that mouth rinse containing fluoride can reduce the number of $\mathrm{S}$. mutans colonies. $\underline{21}$ A high content of minerals in Zamzam water make it has high potential to be used as anticaries agent.

\section{CONCLUSION}

Gargled with Zamzam water can increase salivary $\mathrm{pH}$.

\section{REFERENCE}

1. RISKESDAS T. Laporan nasional RISKESDAS 2018. Jakarta: Lembaga Penerbit Badan Penelitian dan Pengembangan Kesehatan; 2019. 206 p.

2. Frecken JE. Dental caries and caries epidemiology. In: Evidence-based caries prevention. Switzerland: Springer International Publishing; 2016. 1-2 p.

3. Fejerskov O, Larsen MJ. Demineralization and remineralization: the key to understanding clinical manifestasion of dental caries. In: Dental caries: the disease and its clinical management. $3^{\text {rd }}$ ed. Wiley Blackwell; 2015. 7-8, 156-63 p.

4. Robinson C, Weatherell JA, Kirkham J. The chemistry of dental caries. In: Dental enamel formation to destruction. CRC Press; 2018. 234-6 p.

5. Dodds M, Roland S, Edgar M, Thornhill M. Saliva A review of its role in maintaining oral health and preventing dental disease. BDJ Team. 2015;2(1):15123.

6. Baliga S, Muglikar S, Kale R. Salivary pH: A diagnostic biomarker. J Indian Soc Periodontol. 2013;17(4):4615.

7. Shomar B. Zamzam water: Concentration of trace elements and other characteristics. Chemosphere. 2012;86(6):600-5.

8. Khalid N, Ahmad A, Khalid S, Ahmed A, Irfan M. Mineral composition and health functionality of Zamzam water: A review. Int J Food Prop. 2014;17(3):661-77.

9. Omar UM, Al Doghaither HA, 
Rahimulddin SA, Al Zahrani SM, Al-Ghafari AB. In vitro cytotoxic and anticancer effects of Zamzam water in human lung cancer (A594) cell line. Malays J Med Sci. 2017;24(3):15-25.

10. Bamosa A. Zamzam water ameliorates oxidative stress and reduces hemoglobin A1c in Type 2 diabetic patients. J Diabetes Metab. 2013;04(03):2-6.

11. Abdullah AM, Abdelsalam E, Abdullah B, Khaled A. Antioxidant effects of Zamzam water in normal rats and those under inducedoxidative stress. J Med Plants Res. 2012;6(42):5507-12.

12. Alfarizi ME, Fauzi A. Manfaat air zamzam terhadap pencegahan osteoporosis the benefits of Zamzam water on prevention of osteoporosis. Majority. 2016;5(2):56-61.

13. Ali H. Fahad AA-W. Effect of casein phosphopeptide-amorphous calcium phosphate on the microhardness and microscopic features of the sound enamel and initial caries-like lesion of permanent teeth, compared to fluoridated agents. J Bagh Coll Dent Bagh Coll Dent. 2012;24(4):114-20.

14. Ramadhani S, Chairani S, Hestiningsih T. Efek mengunyah mentimun (Cucumis sativus) terhadap laju alir dan $\mathrm{pH}$ saliva. Bali Dent J. 2019;3(2):92-5.

15. Panchal V, Gurunathan D. Comparison of salivary $\mathrm{pH}$ changes with tap water and mineral water rinse after $50 \%$ sucrose solution rinse: a cross-over trial. J Clin Diagnosis Res. 2017;6(1):1-5.

16. Alfadul SM, Khan MA. Water quality of bottled water in the kingdom of Saudi Arabia: A comparative study with Riyadh municipal and Zamzam water. $\mathbf{J}$ Environ Sci Heal Part A. 2011;46(13):1519-28.
17. Abbate GM, Levrini L, Caria MP. Salivary $\mathrm{pH}$ after a glucose rinse: effect of a new mucoadhesive spray (Cariex) based on sodium bicarbonate and xylitol. J Clin Dent. 2014;25(4):71-5.

18. Wulandari P, Lestari F. pH dan kapasitas buffer saliva dalam hubungannya terhadap pembentukan kalkulus pada pasien di instalasi periodonsia RSGM USU. dentika Dent J. 2014;18(2):116-9.

19. Osso D, Kanani N. Antiseptic mouth rinses: an update on comparative effectiveness, risks and recommendations. J Dent Hyg JDH. 2013;87(1):10-8.

20. Dehghan M, Tantbirojn D, KymerDavis E, Stewart CW, Zhang YH, Versluis A, et al. Neutralizing salivary $\mathrm{pH}$ by mouthwashes after an acidic challenge. $\mathrm{J}$ Investig Clin Dent. 2017 ;8(2).

21. Perala SR, Bhupathiraju P. Efficacy of four fluoride mouth rinses on Streptococcus mutans in high caries risk children - a randomized controlled trial. J Clin Diagn Res. $2016 ; 10(9): 56-60$. 